NBER WORKING PAPER SERIES

\author{
OPEN ACCESS RENEWABLE \\ RESOURCES: TRADE AND TRADE \\ POLICY IN A TWO-COUNTRY MODEL
}

James A. Brander

M. Scott Taylor

Working Paper 5474

\author{
NATIONAL BUREAU OF ECONOMIC RESEARCH \\ 1050 Massachusetts Avenue \\ Cambridge, MA 02138 \\ March 1996
}

We thank Rob Feenstra, Guofu Tan, and seminar participants at the National Bureau of Economic Research 1995 Summer Institute for helpful comments on an earlier draft. Financial support from the Social Sciences and Humanities Research Council of Canada and the UBC Centre for International Business Studies is gratefully acknowledged. This paper is part of NBER's research program in International Trade and Investment. Any opinions expressed are those of the authors and not those of the National Bureau of Economic Research.

(C) 1996 by James A. Brander and M. Scott Taylor. All rights reserved. Short sections of text, not to exceed two paragraphs, may be quoted without explicit permission provided that full credit, including $\odot$ notice, is given to the source. 


\title{
OPEN ACCESS RENEWABLE \\ RESOURCES: TRADE AND TRADE \\ POLICY IN A TWO-COUNTRY MODEL
}

\begin{abstract}
This paper develops a two-good, two-country model with national open access renewable resources. We derive an appropriate analog of "factor proportions" for the renewable resource case and link it to trade patterns and to the likelihood of diversified production. The resource importer gains from trade. However, a diversified resource exporting country necessarily suffers a decline in steady state utility resulting from trade, and may lose along the entire transition path. Thus the basic "gains from trade" presumption is substantially undermined by open access resources. Tariffs imposed by the resource importing country always benefit the resource exporter, and may be pareto-improving.
\end{abstract}

James A. Brander

Faculty of Commerce

University of British Columbia

Vancouver, B.C. V6T 1 Z2

CANADA

and NBER
M. Scott Taylor

Department of Economics

University of British Columbia

Vancouver, B.C. V6T 1Z1

CANADA

and NBER 


\section{Introduction}

Many observers assert that major renewable resources such as fish and forest stocks have recently been subject to excessive exploitation. For example, Weber (1995) reports significant depletion in "nearly all" coastal fisheries around the world. An extreme case is the Newfoundland Cod fishery (off the coast of Canada's Newfoundland province) where, by 1992, stocks had fallen to less than $5 \%$ of their levels of the early 1960 s and the fishery was closed. ${ }^{1}$

It is not impossible that such resource depletion is an efficient response to changing circumstances, particularly population growth. However, it seems more likely that such situations represent genuine and substantial market failures. The nature of the market failure is incomplete property rights. It has been wellunderstood at least since the pioneering work of Gordon (1954) that over-exploitation may occur when a renewable resource is subject to open access (i.e. when property rights are completely absent). More generally, any incompleteness of property rights may give rise to inefficient resource utilization.

In the presence of incomplete property rights over renewable resources, it is far from obvious that international trade will necessarily be welfare-improving, and there are several pieces of anecdotal evidence suggesting that some countries have been made worse off trade liberalizations that have led them to exploit renewable resources more aggressively than they should have. Possible examples, as discussed by Brown (1995), include the Ivory Coast and the Philippines, both of which dramatically increased harvesting and exporting of forest products in the 1970 s, substantially depleted their forest stocks, and now have much lower levels of earnings from their forest resources. In the case of the Ivory Coast, the decline of forest

'Lear and Parsons (1993) provide a diagram of the biomass (stock) of spawning Northern cod showing this stock to be about 1.6 million tons in 1962, and under 80,000 tons in 1992 when the fishery was closed. This paper also provides a valuable general history of the management of this fish stock which, among other things, points out that this had been one of the world's most productive fisheries since commercial fishing of the stock began in the year 1501 . The stock was several damaged by dramatic increases in the catch occurring between 1958 and 1970. Subsequent catch reductions were never enough to allow recovery of the stock. 
based export earnings from a high of $\$ 300$ million per year in the 1970 s to about $\$ 30$ million per year in the early 1990s was a significant factor in the approximate $50 \%$ decline in per capita real income that occurred between 1980 and 1994.

There is now substantial policy-level interest in linking trade sanctions to resource management practices. There has, however, been relatively little formal economic analysis addressing such concerns. In a first step towards such analysis, Brander and Taylor (1995) consider the case of a small open economy with an open access renewable resource. That paper obtains the striking result that if the small open economy has a comparative advantage in the resource good and remains diversified in production after trade, then its steady-state utility is necessarily reduced by trade. On the other hand, if the country has a comparative disadvantage in the resource good, then its steady state utility is necessarily increased by trade. Such analysis suggests that countries like Taiwan and Hong Kong might benefit from trade liberalization, whereas countries like the Philippines and the Ivory Coast might be damaged.

In this paper we attempt to take another significant step forward in understanding the relationship between trade and renewable resource management. Specifically, we wish to go beyond the small country case and allow the world price of the resource good to be endogenously determined within the model. This is important as it allows us to examine how one country's trade and resource management practices affect resource stocks and welfare elsewhere in the world. Given the extensive current policy-level discussion of possible linkages between trade policy sanctions and resource management practices, we also wish to consider the possible effects of policy changes on trade patterns and on welfare.

The simplest model in which to investigate these issues is a two-country model in which each country is similar to the small country considered in Brander and Taylor (1995). Each country is endowed with a renewable resource stock and labor, and may produce the resource good and/or a numeraire good which we refer to as manufactures. The renewable resource is subject to domestic open access (i.e. foreigners cannot use the resource) and has a dynamic structure of the classic Shaefer (1957) type. 
Using this model we are able to obtain several interesting results. First, we are able to find an analog of "factor proportions" for the case of a renewable resource model. We are then able to cleanly link trade patterns to relative factor service flows, deriving a result similar in structure to the Heckscher-Ohlin theorem. In addition, we show that sufficient similarity across countries in this ratio of factor proportions ensures diversified production and factor price equalization in steady state. Secondly, we show that the "resource abundant" country necessarily suffers a reduction in its steady state utility as a result of trade. (This result can be viewed as an extension of the small-country result reported in Brander and Taylor (1995).) Moreover, we show that if the resource exporter is always diversified, then it loses at every point along the transition path from autarky to the trading steady state.

Our analysis of policy shows that an import tariff imposed by the country importing the resource good raises the steady state utility of the resource exporter, and may be pareto-improving. This result lends some support to the argument in favor of linking tariffs or other trade sanctions to resource management practices. In addition we show that export taxes on the resource good increase the steady state resource stock in the resource exporting country but reduce the importing country's stock. The resource exporter necessarily gains from a small export tax, while the importer loses.

This work draws on traditional (Ricardian and factor proportions) trade theory, and on the theory of renewable resources. Suitable background for the trade theory component of our analysis is available in standard references such as Dixit and Norman (1980) and Ethier (1984). Papers focusing on trade and growth such as Srinivasan and Bhagwati (1980) and Deardorff (1973) also provide useful comparative background. As for the renewable resource component, our paper builds on the classic work of Shaefer (1957) and Gordon (1954), and much of the analytical background to our paper is set out in the comprehensive overview of "bioeconomics" provided by Clark (1990). Other valuable overviews include Munro and Scott (1985) and Neher (1990). The literature on trade in renewable resources is relatively modest in scope. The review article by Kemp and Long (1984) contains some material on renewable 
resources, and early papers dealing with trade and renewable resources include McRae (1978), Markusen (1976), and Scott and Southey (1969). A related recent paper is Lopez (1994).

There has been extensive recent analysis of the relationship between trade and the environment, including Barrett (1994), Chichilnisky (1994), Conrad (1993), Copeland and Taylor (1994, 1995), and Rauscher (1994). Valuable overviews of international resource management problems are provided in books by Pearce and Warford (1993) and Cooper (1994). Overall, however, we view this paper, along with Brander and Taylor (1995), as a substantial departure from existing themes in the literature.

\section{General Equilibrium with a Renewable Resource: Autarky}

\subsection{Renewable Resource Growth}

As in Brander and Taylor (1995) it is necessary to begin by describing the basic structure of renewable resource growth. Each country has a resource stock. Focusing on just one country for now, referred to as the "domestic" country, its resource stock at time $t$ is denoted $S(t)$. The natural growth of the resource, denoted $\mathrm{G}$, is a function of the existing stock. The change in the stock at time $t$ is the natural growth rate $G(S(t))$, minus the harvest rate, $H(t)$. Dropping the time argument for convenience yields

$$
\mathrm{d} \mathbf{S} / \mathrm{dt}=\mathrm{G}(\mathbf{S})-\mathbf{H} \text {. }
$$

We use a specific functional form for $\mathrm{G}$, given by

$$
\mathrm{G}(\mathrm{S})=\mathrm{rS}(1-\mathrm{S} / \mathrm{K}) \text {. }
$$

This functional form for $G(S)$ is the logistic function. It is widely used in the analysis of renewable resources and is perhaps the simplest empirically plausible functional form for biological growth in a constrained environment. The variable $\mathrm{K}$, referred to as the "carrying capacity", is the maximum possible size for the resource stock. If $S=K$, further growth cannot occur. The variable $r$ is the "intrinsic" or "uncongested" growth rate. Note that proportional growth rate $\mathrm{G}(\mathrm{S}) / \mathrm{S}$ would be approximately equal to $\mathrm{r}$ if congestion were negligible in the sense that carrying capacity were large relative to the current stock.

\subsection{Production and Supply}


Each country produces and consumes two goods. $\mathrm{H}$ is the harvest of the renewable resource, and $\mathbf{M}$ is some other good which might be thought of as manufactures. Good $\mathbf{M}$ is treated as a numeraire whose price is normalized to 1 . In addition to the resource stock $S$, there is only one other factor of production, labor, L. Manufactures are produced with constant returns to scale using only labor. By choice of units, one unit of labor produces one unit of good $\mathbf{M}$. As the price of $\mathbf{M}$ is 1 , it follows that labor's value of marginal product in manufacturing is 1 . We assume that labor markets are perfectly competitive, thus the wage in manufacturing is 1 . We also assume that harvesting is carried out according to the Shaefer harvesting production function.

$$
\mathrm{H}^{\mathrm{P}}=\alpha \mathrm{SL}_{\mathrm{H}}
$$

where $\mathrm{H}^{\mathrm{P}}$ is the harvest supplied by producers. (The superscript $\mathrm{P}$ stands for "production" .) $\mathrm{L}_{\mathrm{H}}$ is the amount of labor used in resource harvesting and $\alpha$ is a positive constant. Letting $\mathrm{a}_{\mathrm{LH}}(S)$ represent the unit labor requirement in the resource sector, (3) implies that $a_{L H}(S)=L_{H} / H^{P}=1 / \alpha S$. Note that $a_{L H}{ }^{\prime}(S)<0$ : unit labor requirements rise as the resource stock falls. Production in both sectors is carried out by profitmaximizing firms operating under conditions of free entry. Thus the price of the resource good must equal its unit cost of production.

$$
\mathrm{p}=\mathrm{wa}_{\mathrm{LH}}=\mathrm{w} / \alpha \mathrm{S}
$$

where $w$ is the wage. Condition (4) incorporates the open-access assumption, because it means that labor costs are the only explicit cost of production. There is no explicit rental cost for using S. Labor is mobile between the two sectors. Thus if manufactures are produced, the wage must be 1 , and $p=1 / \alpha S$.

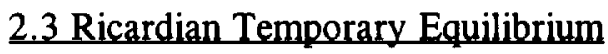

A representative consumer is endowed with one unit of labor and is assumed to have instantaneous utility given by the following Cobb-Douglas utility function

$$
\mathrm{u}=\mathrm{h}^{\beta} \mathrm{m}^{1-\beta}
$$

where $\mathrm{h}$ represents individual consumption of the resource good, $\mathrm{m}$ is individual consumption of 
manufactures, and taste parameter $\beta$ is strictly between 0 and 1 . The consumer maximizes utility at each moment in time subject to an instantaneous budget constraint $\mathrm{ph}+\mathrm{m}=\mathrm{w}$. This maximization yields demand functions $h=w \beta / p$ and $m=w(1-\beta)$. Total domestic demand is just $L$ times individual demand. Thus, using superscript $C$ to represent consumption, we have

$$
H^{c}=w \beta L / p ; M^{c}=w(1-\beta) L .
$$

Rearranging the left hand expression in (6), the inverse demand for the resource good can be written as

$$
p=w \beta L / H^{c} .
$$

On the production side, at a moment in time the resource stock is fixed, and the economy is Ricardian. The full employment condition defines the temporary Ricardian production possibility frontier (PPF) and is given by $\mathrm{H}^{\mathrm{P}} \mathrm{a}_{\mathrm{LH}}(\mathrm{S})+\mathrm{M}=\mathrm{L}$. The temporary equilibrium harvest can be determined by setting the supply price given by (4) equal to the demand price given by (7) (i.e. by setting supply equal to demand). This yields

$$
H=\alpha \beta L S .
$$

Note that the temporary equilibrium harvest is an increasing linear function of the stock. The equilibrium output of $M$ is $M=(1-\beta) L$, hence fraction $\beta$ of the labor force is employed in the resource sector.

\subsection{An Autarkic Steady-State}

The temporary equilibrium is like a standard Ricardian equilibrium. However, there is no guarantee that the harvest will equal the underlying biological growth rate of the resource. If, for example, the temporary equilibrium harvest, $\mathrm{H}$, exceeds biological growth $\mathrm{G}$, then the stock diminishes as time proceeds. As a result, labor productivity in the resource sector falls. (From (3) the average and marginal product of labor is $\alpha \mathrm{S}$, which obviously falls as S falls.) The Ricardian PPF, which has harvest intercept $\alpha \mathrm{LS}$, then pivots inward, leading to a new temporary equilibrium, as illustrated in Figure 1 .

\section{FIGURE 1 HERE}

A steady state emerges when the stock has evolved to a level at which $\mathrm{H}(\mathrm{S})$ as given by (8) is equal 
to $G(S)$ as given by (2). Setting these equal yields

$$
\alpha \beta \mathrm{LS}=\mathrm{rS}(1-\mathrm{S} / \mathrm{K})
$$

One solution to (9) occurs when $S=0$. Thus $S=H=0$ is a possible (and miserable) steady state. If $S$ is not zero, we obtain the solution

$$
S_{\mathrm{A}}=\mathrm{K}(1-\alpha \beta \mathrm{L} / \mathrm{r})
$$

where $S_{A}$ stands for the autarkic steady state resource stock. The resource dynamics associated with convergence to a steady state are illustrated in Figure 2 . This figure illustrates a situation in which the initial stock level, $S_{0}$, implies a harvest $H\left(S_{0}\right)$ in excess of natural growth $G\left(S_{0}\right)$. Thus the stock shrinks toward its autarkic steady state level $\mathrm{S}_{\mathrm{A}}$.

\section{FIGURE 2 HERE}

The steady state harvest is obtained by substituting (10) into (8).

$$
\mathrm{H}_{\mathrm{A}}=\alpha \beta \mathrm{LK}(1-\alpha \beta \mathrm{L} / \mathrm{r})
$$

As shown in Brander and Taylor (1995), a positive steady state solution exists if and only if

$$
\mathrm{r} / \mathrm{L}>\alpha \beta
$$

in which case the solution is globally stable (for $S_{0}>0$ ). If (12) is not satisfied, the resource will be extinguished and the unique steady state is $S=H=0$. To appreciate the meaning of (12) note (from (2)) that $r$ is proportional to $G$, the instantaneous growth rate of the resource. Thus $r$ is a measure of the service flow from the resource stock, and the ratio $\mathrm{r} / \mathrm{L}$ measures the relative factor service flow. Expression (12) can then be interpreted as saying that a positive steady state exists only if "factor proportion" $\mathrm{r} / \mathrm{L}$ implies sufficient resource abundance.

\subsection{A Two-Country Model of International Trade}

We now consider trade between two countries that are identical except for factor proportions. In particular, each country has a renewable resource that is subject to open access by residents of that country only. We therefore abstract from the international open access problem. The international aspect of open 
access is interesting and important, but the case of nationally controlled open access resources is much more empirically significant. ${ }^{2}$ Both goods may be traded, but labor is immobile across countries.

As suggested earlier, a useful measure of comparative advantage is given by factor proportion ratio $\mathrm{r} / \mathrm{L}$. We refer to the countries as "foreign" and "domestic" and use asterisks to denote foreign variables. For concreteness, we take the foreign country to be relatively resource abundant and the domestic country to be labor abundant. ${ }^{3}$

$$
\mathrm{r}^{*} / \mathrm{L}^{*}>\mathrm{r} / \mathrm{L}
$$

We assume that the parameters are such that each country has a positive steady state resource stock in autarky (i.e. expression (12) holds for each country), and then consider trade.

\subsection{The Positive Analysis of Trade}

Most of our attention is devoted to comparative steady state analysis, but we begin with a brief description of the dynamic transition that occurs when trade opens. We provide a more formal analysis of a transition path in Section 3.4.

At each point in time, both countries have a Ricardian production structure and comparative advantage is determined purely by a comparison of home and foreign resource stocks. Labor markets and goods markets clear instantaneously and the only dynamic adjustment arises from the evolution of the resource stocks over time.

Before trade opens, both countries are assumed to be in a (diversified) autarkic steady state. As

2 In a recent comprehensive review of international fisheries research conducted by the U.N. Development Program, the Commission of European Communities, the World Bank, and the Food and Agriculture Organization of the U.N, the authors conclude that "Although states have largely ended international open access through the extension of jurisdiction, most still allow free and open access to their domestic fisheries." (original emphasis) World Bank et. al. (1992; p14). Accordingly we take domestic open access as our working hypothesis.

${ }^{3}$ While we focus on cross-country differences in $r / L$ as the central asymmetry between countries, differences in other parameters such as $\alpha$ (harvesting efficiency) and $\mathrm{K}$ (carrying capacity) would also have interesting consequences. 
trade opens, both countries are producing manufactures, implying that the wage is 1 in both countries. It follows from equation (10) and condition (13) that the foreign country has the higher resource stock. Using (4) (with $w=1$ ) and its foreign counterpart (with $w^{*}=1$ ), we can then infer that the foreign supply price for the resource good is less than the domestic supply price. The foreign country will therefore begin to export the resource good, while the domestic country must export manufactures (as implied by instantaneous trade balance). The exact pattern of world trade and production at a moment in time is determined by the strength of tastes for the resource good $(\beta)$, by relative labor endowments, and by resource stocks $S$ and $S^{*}$.

In order to export the resource good, the foreign country initially raises its harvest above the autarky level. In the pre-trade steady state, the foreign harvest and the foreign resource growth rate were equal. As trade opens, the harvest rate rises instantaneously, implying that it must exceed the resource growth rate, which only changes slowly as $S^{*}$ evolves. The foreign resource stock must therefore start to fall. In contrast, the domestic country imports the resource good, lowers its harvest rate below the autarky level (and below the corresponding resource growth rate), and therefore allows the stock to grow. Thus the initial differences across countries in resource stocks that initiate trade must diminish as a result of the production shifts caused by trade. International trade moves the resource stocks toward equalization as time proceeds. This process of stock adjustment continues until the world economy reaches either a diversified or specialized steady state.

If world demand for the resource good is very high, or if countries differ substantially in factor proportions, then the foreign country may specialize in the resource good in steady state. Conversely, a lower level of world demand for the resource good or a greater degree of similarity between the two countries in factor proportions will lead to diversification of production in both countries, as demonstrated in Proposition 4. These are the only two possibilities for the steady state pattern of production. In this paper we focus on the diversified case. The specialized case is of some interest, but we view it as less empirically 
relevant and, given space constraints, we do not pursue it here. Proposition 4 states precisely when specialization and diversification will occur. First, however, we report some basic facts about trade under diversification.

\section{Proposition 1:}

If each country remains diversified in production after trade, then

i) (factor price equalization, FPE) the wage must be equal to 1 in each country $\left(w=w^{*}=1\right.$ ), and

ii) (resource stock equalization, RSE) each country will have the same resource stock ( $S=S^{*}$ ).

Proof: i) If each country is diversified, then each produces some manufactures, where the marginal value product of labor is 1 , which implies that the wage is 1. ii) From expression (4) and from (i), it follows that $\mathrm{p}_{\mathrm{T}}=\mathrm{a}_{\mathrm{LH}}=\mathrm{a}^{*}{ }_{\mathrm{LH}}$, where $\mathrm{p}_{\mathrm{T}}$ is the world price of the resource good. Then, as $\mathrm{a}_{\mathrm{LH}}=1 / \alpha \mathrm{S}$, while $\mathrm{a}_{\mathrm{LH}}^{*}=$ $1 / \alpha S^{*}$, it follows that $S=S^{*} . * *$

Note that proposition 1 does not depend on being in a steady state, but applies at each point in time. Whenever production is diversified, wages and resource stocks must be equalized. Because Proposition 1 indicates that diversified production ensures that trade eliminates comparative advantage (at the margin) across countries and induces FPE, it bears a striking resemblance to predictions of conventional factor proportions models.

Given that changing production patterns across countries are the mechanism by which resource stocks are equalized, and given that preferences are Cobb-Douglas and therefore homothetic we might hope that the pattern of trade can be linked to factor proportions. This is established by Proposition 2 .

\section{Proposition 2:}

In a diversified trading steady state, the resource abundant country must export the resource good. The labor abundant country must export manufactures (the labor intensive good).

Proof: From expression (8) we have $\mathrm{H}^{\mathrm{c}}=\mathrm{L} \alpha \beta S$ and $\mathrm{H}^{\mathrm{c} *}=\mathrm{L}^{*} \alpha \beta S^{*}$. Recalling from Proposition 1 that $S=S^{*}$, it follows that $H^{C} / H^{C^{*}}=L / L^{*}$. Production in steady state requires $H=G$ and $H=G^{*}$. 
Therefore $\mathrm{H}^{\mathrm{P}} / \mathrm{H}^{\mathrm{P} *}=\mathrm{G} / \mathrm{G}^{*}=\mathrm{r} / \mathrm{r}^{*}$. We then obtain $\left(\mathrm{H}^{\mathrm{C}} / \mathrm{H}^{\mathrm{P}}\right) /\left(\mathrm{H}^{\mathrm{C}^{*}} / \mathrm{H}^{\mathrm{P} *}\right)=(\mathrm{L} / \mathrm{r}) /\left(\mathrm{L}^{*} / \mathrm{r}^{*}\right)>1$, or $\mathrm{H}^{\mathrm{C}} / \mathrm{H}^{\mathrm{P}}>$ $H^{C^{*}} / H^{P^{*}}$. The material balance condition given by $H^{c}+H^{C^{*}}=H^{P}+H^{P^{*}}$ then implies that $H^{C}>H^{P}$. Thus the labor abundant country consumes more of the resource good than it produces and must import it. It follows that the resource abundant country must export the resource good.

As in standard factor proportions models, relative resource abundance determines autarky relative prices, which in turn predict the direction of trade. Unlike standard factor proportions models, however, the mechanism by which this occurs is that production reallocations across countries cause resource stocks to be equalized. Proposition 3 establishes the natural intuition about post-trade resource stock and price levels.

\section{Proposition 3.}

In a diversified trading steady state,

i) the common post-trade steady state resource stock in each country, denoted $S_{\mathrm{T}}$, lies between the autarky and steady state stock sizes, and

ii) the post-trade world price of the resource good lies between the autarky prices.

Proof: i) By material balance, $\mathrm{H}^{\mathrm{C}}+\mathrm{H}^{\mathrm{C} *}=\mathrm{G}\left(\mathrm{S}_{\mathrm{T}}\right)+\mathrm{G}^{*}\left(\mathrm{~S}_{\mathrm{T}}\right)$ or, using (8) and (2),

$$
\alpha S_{\mathrm{T}}\left(\beta\left(\mathrm{L}+\mathrm{L}^{*}\right)\right)=\mathrm{rS}_{\mathrm{T}}\left(1-\mathrm{S}_{\mathrm{T}} / \mathrm{K}\right)+\mathrm{r}^{*} \mathrm{~S}_{\mathrm{T}}\left(1-\mathrm{S}_{\mathrm{T}} / \mathrm{K}\right) \text {. }
$$

Rearrangement of (14) yields a solution for the diversified steady state stock in each country.

$$
S_{T}=K\left[1-\left(L+L^{*}\right) \alpha \beta /\left(r+r^{*}\right)\right]>0 .
$$

Comparing expression (15) with expression (10) completes the proof.

ii) Diversification of production implies (using (4) with $w=1$ ) that $p=1 / \alpha S$ and $p^{*}=1 / \alpha S^{*}$ before trade, and also that $\mathrm{p}_{\mathrm{T}}=1 / \alpha \mathrm{S}_{\mathrm{T}}$ after trade. Using part i) then implies $\mathrm{p}>\mathrm{p}_{\mathrm{T}}>\mathrm{p}^{*}$, as was to be shown.***

Propositions 1, 2, and 3 presume that both countries remain diversified in production after trade. Whether diversification occurs in steady state depends on the similarity across countries in factor proportions and the strength of tastes for the resource good, as follows from Proposition 4. 


\section{Proposition 4}

i) Neither country can specialize in manufactures.

ii) A necessary and sufficient condition for the post-trade pattern of production to be diversified in both countries is

$$
\left[\left(\mathrm{L}^{*} / \mathrm{r}^{*}\right)\right] /\left[\left(\mathrm{L}+\mathrm{L}^{*}\right) /\left(\mathrm{r}+\mathrm{r}^{*}\right)\right]>\beta .
$$

iii) If (16) fails to hold, then the foreign (resource abundant) country will specialize in production of the resource good and the domestic country will be diversified. This is the only specialization possibility.

Proof: See Appendix.

The left hand side of expression (16) is a measure of the similarity of factor proportions across countries. If the countries are identical up to scalar multiples (i.e. $r=\gamma \mathrm{r}^{*}$ and $\mathrm{L}=\gamma \mathrm{L}^{*}$ for some $\gamma>0$ ) then $\mathrm{r} / \mathrm{L}=\mathrm{r}^{*} / \mathrm{L}^{*}$ and condition (16) reduces to $1>\beta$, which is true by model construction. Thus sufficient similarity in factor proportions implies that (16) must be satisfied, which in turn implies that diversification (and therefore FPE) follow.

We can increase the difference in factor proportions while maintaining the relative factor abundance assumption by increasing $\mathrm{L} / \mathrm{r}$ or decreasing $\mathrm{L}^{*} / \mathrm{r}^{*}$. In either case, (16) is more likely to be violated. In addition, increases in $\beta$ (reflecting the world taste for the resource good) make (16) more likely to be violated. If (16) is violated, then factor prices will not be equalized by trade and the foreign country will specialize in production of the resource good in steady state. In effect, Proposition 4 points out that the possibility of FPE depends both on relative resource endowments and on tastes, as in conventional factor proportions theory. (A standard reference on FPE is Dixit and Normam (1980), but see Deardorff (1994) for some new results and a very recent perspective.)

The model is Ricardian at each point in time. Nevertheless, Propositions 1 through 4 show that the steady state properties of the model are surprisingly similar to standard factor proportions models, at least at the level of positive analysis. A measure of relative resource abundance determines "comparative 
advantage", and trade flows are reliably predicted by this measure. Moreover, if the countries are sufficiently similar in factor proportions, then trade will bring about diversified production and FPE.

\subsection{Normative Steady State Implications of Trade}

Despite the similarities between our renewable resource model and standard factor proportions models, we can now establish a result that contrasts sharply with the basic normative insight associated with the theory of comparative advantage.

\section{Proposition 5:}

Comparing a diversified trading steady state with autarky,

i) trade causes steady state utility to fall in the resource-abundant country, and

ii) trade causes steady state utility to rise in the labor-abundant country.

Proof: i) The foreign country has autarky consumption possibilities given by its PPF, $\mathrm{H}^{*} \mathrm{a}_{\mathrm{a}}{ }_{\mathrm{LH}}\left(\mathrm{S}_{\mathrm{A}}{ }^{*}\right)+\mathrm{M}^{*}$ $=\mathrm{L}^{*}$ (noting that $\mathrm{H}^{* \mathrm{C}}=\mathrm{H}^{* \mathrm{P}}$ under autarky and letting $\mathrm{S}_{\mathrm{A}}^{*}$ be the autarky steady state resource stock). After trade, the foreign country must consume on a budget line running through the production point with slope equal to the world terms of trade. This is its post-trade steady state PPF. The equation of this line

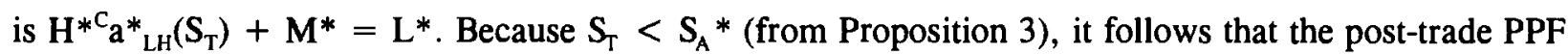
lies inside the autarky consumption (and production) possibility frontier, except at the corner where $\mathbf{M}^{*}$ $=\mathrm{L}^{*}$. As autarky consumption was not at this corner, foreign steady state utility must be lower in the trading steady state than under autarky.

ii) This follows from parallel reasoning for the home country, except that, as $S_{T}>S_{A}$, the home country experiences steady-state gains from trade.

One way of seeing that foreign utility must fall in the move from autarky to a trading steady state is to observe that, relative to autarky, foreign nominal income stays constant (at $\mathrm{L}^{*}$ ), the price of manufactures stays constant (at 1), and the price of the resource good rises (from Proposition 3). Therefore, the representative foreign consumption bundle must shrink and foreign utility must fall. 
Proposition 5 is the analog to the result in Brander and Taylor (1995) that a resource abundant small open economy that remains diversified after trade has a lower steady-state utility level after trade than in autarky. Taken together, Brander and Taylor (1995) and Proposition 5 undercut the gains from trade presumption for trade based on the exploitation of a renewable resource under conditions of incomplete property rights.

Because open access creates a market failure, there is no presumption that removing another distortion (prohibitions on trade) will necessarily improve welfare. This is implied by standard second best reasoning. It is important, however, to move beyond this relatively uninformative statement to an examination of the conditions under which trade can be shown to be either welfare-enhancing or welfaredecreasing. In our model we can clearly identify the two forces at work: resource depletion effects and terms of trade effects. Any country that further depletes its resource stock as a result of trade necessarily lowers its Ricardian PPF. By itself, such depletion tends to lower steady state utility. However, standard terms of trade effects work in the other direction. Even a country that reduces its resource stock may have greater consumption possibilities if the world relative price of the resource good is sufficiently high.

In our simple framework, a diversified country always has a constant marginal rate of transformation equal to the world terms of trade. Its PPF is therefore equivalent to its consumption possibility frontier, as in the standard Ricardian model. Resource depletion causes the foreign PPF to pivot inward, skrinking its consumption set and reducing the maximum attainable utility. The only way the foreign country could take advantage of terms of trade effects would be to specialize in the resource good and experience an increase in the wage. However, specialization will only occur if (16) is violated (i.e. if difference between foreign and domestic relative resource abundance is sufficiently great).

Brander and Taylor (1995) show that a similar "losses in steady state" result occurs in a small resource exporting economy when its intrinsic resource growth rate, $r$, is low and its labour force is large. We have now shown, with endogenous world prices, that if the two countries are sufficiently similar in 
factor proportions, then diversification necessarily occurs in a trading steady state (Proposition 4), and this trading steady state necessarily provides lower foreign utility than autarky (Proposition 5).

\subsection{Normative Analysis of Transitional Dynamics}

We now consider the welfare properties of the dynamic transition from autarky to the new posttrade steady state. Even when trade leads to diversified production and lower steady state utility for the foreign country, it may provide utility gains during the transition period. This seems an important qualification to our analysis, but we show that there are reasonable conditions under which the foreign country loses at every point on the transition path as well as in steady state.

The key to understanding this possibility follows from our intuition regarding terms of trade and resource depletion effects. If the foreign country remains diversified throughout the transition process then, because of ongoing resource depletion effects, utility would be lower at each point in time in trade than in autarky. The aggregate present value of foreign welfare would then necessarily be reduced by trade, regardless of the discounting rule used.

One condition underlying transitional losses from trade for the foreign country is

$$
L^{*}>\beta\left(L+L^{*}\right)
$$

Rearranging (17) yields $(1-\beta)\left(L+L^{*}\right)>L$. Wage rates $w$ and $w^{*}$ cannot be less than 1 . Therefore,

$$
(1-\beta)\left(w L+w^{*} L^{*}\right)>L .
$$

However, it follows from the right hand expression in (6) that world demand for manufactures is precisely the left hand side of expression (17a). Therefore, world demand exceeds $\mathrm{L}$. But $\mathrm{L}$ is the maximum amount of manufactures that can be produced in the domestic country even if all domestic labor is devoted to manufactures. It follows that the foreign country must in this case (i.e. if (17) holds) produce some manufactures and have a wage equal to 1 at every point on the transition path. Condition (17) also implies that (16) holds and therefore insures convergence to a diversified steady state.

Now consider what happens when trade opens. As established in Section 3.2, expression (10) 
implies that the initial resource stock is higher in the foreign country than in the domestic country. Furthermore, foreign and domestic wages equal 1 . We can then infer from (4) that the supply price of the resource good in the foreign country must be less than the supply price in the domestic country. Therefore, the domestic country cannot sell the resource good, as it will be undercut by foreign producers, so it must specialize in manufactures and produce a harvest of zero. The foreign country remains diversified, and the wage remains at 1 in both countries. As long as $S^{*}>S$, the domestic harvest remains zero, and the evolution of the domestic stock (from equation (1)) is given by

$$
\mathrm{dS} / \mathrm{dt}=\mathrm{rS}(1-\mathrm{S} / \mathrm{K})>0
$$

To obtain the corresponding equation for the foreign country, we need to determine its harvest. This can be done by finding the labor allocated to harvesting. With the (specialized) domestic country producing amount $L$ of manufactures, and with world demand for manufactures given by $(1-\beta)\left(L+L^{*}\right)$ (from $(17 a)$ with $\left.w=w^{*}=1\right)$, it follows that foreign production of manufactures is $(1-\beta)\left(L+L^{*}\right)-L$. This must also be the amount of foreign labor devoted to manufacturing, so the amount of foreign labor left over for harvesting is $L^{*}-\left[(1-\beta)\left(L+L^{*}\right)-L\right]=\beta\left(L+L^{*}\right)$. Using (3), we can then observe that the foreign harvest is $H^{*}=\alpha \beta\left(L+L^{*}\right) S^{*}$. Therefore, from (1), the differential equation governing the evolution of the foreign stock (for $S^{*}>S$ ) is

$$
\mathrm{dS}^{*} / \mathrm{dt}=\mathrm{r}^{*} \mathrm{~S}^{*}\left(1-\mathrm{S}^{*} / \mathrm{K}\right)-\alpha \beta\left(\mathrm{L}+\mathrm{L}^{*}\right) \mathrm{S}^{*}
$$

We could integrate (18) and (19) to provide explicit solutions for the trajectory of foreign and domestic stocks. It is easier, however, to draw inferences directly from (18) and (19). From (18), recalling that S $<\mathrm{K}$ as trade opens, we can infer that $\mathrm{S}$ approaches and gets arbitrarily close to $\mathrm{K}$ as time proceeds. To interpret (19) recall (from (8)) that under autarky $\mathrm{r}^{*} \mathrm{~S}^{*}\left(1-\mathrm{S}^{*} / \mathrm{K}\right)=\alpha \beta \mathrm{L}^{*} \mathrm{~S}^{*}$. Therefore (19) must be negative as trade opens. Thus, immediately upon the opening of trade, $S$ starts to grow and $S^{*}$ starts to fall.

As $\mathrm{S}$ grows, eventually one of two things must happen. Either $\mathrm{S}$ must get arbitrarily close to $\mathrm{K}$ (as implied by (18)), or it must equalize with $S^{*}$. Meanwhile, $S^{*}$ would continue to fall either until it reached 
the stabilizing value implied by (19), which is $K\left[1-\alpha \beta\left(L+L^{*}\right) / r^{*}\right]<K$, or until it equalized with $S$. Given that $S^{*}>S$ initially, $S$ and $S^{*}$ must equalize at some finite time. If they did not, $S$ would rise to $K$, while $S^{*}$ would fall to something strictly less than $K$. This cannot happen without $S$ and $S^{*}$ coming to equality at some point. When $S$ and $S^{*}$ do equalize, differential equations (18) and (19) cease to govern the further evolution of the stocks. We denote this time when $S$ and $S^{*}$ equalize as $t_{e}$.

Throughout this entire time up to $t_{e}$ foreign utility is falling. To see this recall that the foreign country remains diversified throughout the process. (This is ensured by condition (17).) Therefore its wage remains at 1 and it total income is $L^{*}$. The price of manufactures remains stable at 1 . The world price of the resource good is determined by the foreign supply price, as only the foreign country produces the resource good. This price starts at the foreign autarky level then rises as the foreign stock declines. (This is implied by the foreign version of $(4)$ with $w^{*}=1$ ). Therefore, the foreign country has a stable nominal income and a steadily increasing real cost of consumption, implying that its utility falls at each point along the transition until $S=S^{*}$ at time $t_{e}$.

Once the two resource stocks are finally equalized, they can never differ from each other again. Any incipient deviation of S from S* would lead to an instantaneous flood of labor into the resource sector of the country with the marginally higher stock, and out of harvesting in the other country. The speed of this production "correction" is instantaneous, whereas stock adjustment occurs in real time (i.e. comparatively slowly). Thus stock deviations can never get started because they are instantaneously swamped by production adjustments.

The two stocks evolve in tandem toward the steady state value $S_{\mathrm{T}}$ given by (15). The value at which $S$ and $S^{*}$ equalize may be above, below, or precisely at $S_{T}$, depending on parameter values. The dynamic behavior of the stocks after time $t_{e}\left(\right.$ i.e. when $\left.S=S^{*}\right)$ is given by

$$
\mathrm{dS} / \mathrm{dt}=\mathrm{rS}(1-\mathrm{S} / \mathrm{K})-\alpha \mathrm{L}_{\mathrm{H}} S=\mathrm{dS} / \mathrm{dt}=\mathrm{r}^{*} \mathrm{~S}^{*}\left(1-\mathrm{S}^{*} / \mathrm{K}\right)-\alpha \mathrm{L}_{\mathrm{H}}{ }^{*} \mathrm{~S}^{*}
$$

Given condition (17), the two countries must both be diversified when stocks are equalized. Therefore 
wages are equal to 1 and (from (17a)) world demand for manufactures is $(1-\beta)\left(L+L^{*}\right)$. Total labor devoted to manufactures must be precisely the same quantity. The remaining amount of labor, $\beta\left(L+L^{*}\right)$, must equal $L_{H}+L_{H} *$. Using (20) and this market-clearing condition allows us to solve for the labor allocations in each country during this phase of the transition. These are given by

$$
\begin{aligned}
\mathrm{L}_{\mathrm{H}} & =(1 / 2)\left[\left[\left(\mathrm{r}^{*} \mathrm{r}^{*}\right) / \alpha\right](1-\mathrm{S} / \mathrm{K})+\beta\left(\mathrm{L}+\mathrm{L}^{*}\right)\right] \\
\mathrm{L}^{*}{ }_{\mathrm{H}} & =(1 / 2)\left[\left[\left(\mathrm{r}^{*}-\mathrm{r}\right) / \alpha\right]\left(1-\mathrm{S}^{*} / \mathrm{K}\right)+\beta\left(\mathrm{L}+\mathrm{L}^{*}\right)\right]
\end{aligned}
$$

where $S=S^{*}$. These allocations apply at each point in time from $t_{e}$ forward along the transition path. Note that the labour allocated to harvesting in each country is equal to half the world's allocation of labour to harvesting, (1/2) $\beta\left(L+L^{*}\right)$, plus a positive or negative term to account for the differential growth rates of the resource.

We can now solve for the transition path of either country's resource stock over the remaining interval of the transition period, $t \in\left[t_{e}, \infty\right)$. Substituting (21) into (20) and rearranging shows that the evolution of the domestic resource stock from its position at $t=t_{e}$ is given by:

$$
\mathrm{dS} / \mathrm{dt}=1 / 2\left[\left(\mathrm{r}+\mathrm{r}^{*}\right) \mathrm{S}(1-\mathrm{S} / \mathrm{K})-\alpha \beta\left(\mathrm{L}+\mathrm{L}^{*}\right) \mathrm{S}\right]
$$

The solution to (23) shows that the domestic stock converges to steady state stock $S_{\mathrm{T}}$ (given in (15)). Furthermore, this convergence is monotonic either from above or below. Substituting (22) into (20) shows that the same properties apply to the foreign stock.

We have already determined that the foreign country has a declining instantaneous utility everywhere along the first part of its transition path towards the trading steady state (i.e. at every time prior to $t_{e}$, when the stocks equalize). We have now shown that over the rest of the transition the foreign stock must rise or fall monotonically toward $S_{T}$, which, from Proposition 3 , is less than its autarky stock, $S^{*}$. Therefore, the foreign stock must always be less than $\mathrm{S}_{\mathrm{A}}{ }_{\mathrm{A}}$ (its autarky level) throughout the entire transition period. Moreover, the world price of the resource good is always equal to $1 / \alpha S^{*}$ (from (4)). Therefore, the world price of the resource good must be higher than in autarky, as $\mathrm{S}^{*}$ is always less than $\mathrm{S}_{\mathrm{A}}$. Once 
again, however, foreign nominal income is steady at $\mathrm{L}^{*}$, and the price of manufactures is steady at 1 . Thus foreign utility must be lower at every point along the transition path. Parallel reasoning implies that the home country gains during the transition. Proposition 6 summarizes this discussion.

\section{Proposition 6.}

If condition (17) holds $\left(L^{*}>\beta\left(L+L^{*}\right)\right)$, then foreign utility is lower at every point along the transition from autarky to free trade than in autarky. Conversely, domestic utility is higher at every point along the transition than in autarky. Therefore, for any plausible discounting procedure, foreign welfare is reduced by trade and domestic welfare is increased by trade.***

If condition (17) does not hold, then the foreign country may gain, depending on parameter values, along some interval of the transition path, even if the steady state is ultimately diversified. In such a case discount rates and adjustment speeds would be important in determining an overall welfare result. Furthermore, if the steady state is specialized, the foreign country may gain from trade along the transition and in steady state. Nevertheless, Propositions 5 and 6 taken together do provide a serious caveat to the "trade lifts all boats" hypothesis when open access renewable resources are present.

\section{Trade Policy}

We now consider possible interventions. There are many policies that might be considered. Rather obviously, the "first-best" policy would be to solve the open access market failure by establishing some system of appropriate property rights. By hypothesis, however, this is either impossible or at least very costly, leading to a search for alternative policy instruments. Given the policy-level debate over resource management and trade policy, the natural first step is to consider a small import tariff on resource good imports by the domestic country. In addition, as many resource exporting countries argue that their export taxes are really tools of resource management, we will also consider a small export tax by the resource exporter. It is fairly straightforward to consider other trade and tax interventions but space limitations 
preclude their examination here. ${ }^{4}$

We restrict attention to comparative steady state analysis with diversified production. As we introduce policy, we need to distinguish between steady state domestic and foreign stock levels. We now use $S$ and $S^{*}$ to refer to the post-trade steady state resource stocks. Similarly, $p$ and $p^{*}$ will refer to posttrade steady state prices in the two countries.

We are interested in how a domestic tariff on the resource good will affect steady state stocks, harvests, prices, and utility levels. The basic methodology is that we imagine an initial tariff of 0 , then consider the introduction of a marginal specific tariff, $\tau$. To carry out the associated comparative steady state analysis we need to see how various endogenous magnitudes must change so as to maintain the steady state material balance requirement, while also maintaining temporary equilibrium requirements for profitmaximization under free entry. In addition, in our perfectly competitive setting we must maintain the condition that domestic and foreign prices differ only by the amount of the tariff, implying that $p=p^{*}+$ $\tau$.

The steady state material balance requirement is based on based on setting expression (1) to 0 for each country. Thus harvesting in each country must equal that country's resource growth in steady state. As world consumption of the resource good $\left(\mathrm{H}+\mathrm{H}^{*}\right)$ must equal the world harvest, expression (24) follows.

$$
\beta I / p+\beta I^{*} / p^{*}=r S(1-S / K)+r^{*} S^{*}\left(1-S^{*} / K\right)
$$

With $\mathrm{w}=\mathrm{w}^{*}=1$, domestic nominal income $\mathrm{I}$ is simply $\mathrm{L}+\tau \mathrm{Z}$, where $\mathrm{Z}$ is imports, and foreign nominal income is $L^{*}$. Noting that production is diversified in both countries, we have $p=1 / \alpha S$ and $p^{*}=1 / \alpha S^{*}$. Making these substitutions, (24) can be rewritten as

$$
A\left(S, S^{*} ; \tau\right)=\beta(L+\tau Z) \alpha S+\beta L^{*} \alpha S^{*}-r S(1-S / K)-r^{*} S^{*}\left(1-S^{*} / K\right)=0
$$

\footnotetext{
4 We have, for example, worked out the implications of production taxes for either country, and have ranked the interventions according to steady state utility.
} 
Also, the condition $p=p^{*}+\tau$ becomes $1 / \alpha S=1 / \alpha S^{*}+\tau$, or

$$
\mathrm{B}\left(\mathrm{S}, \mathrm{S}^{*} ; \tau\right)=1 / \alpha \mathrm{S}-1 / \alpha \mathrm{S}^{*}-\tau=0
$$

Expression (25) and (26) form a two-equation simultaneous system that must be maintained across comparative steady states. We can solve for the comparative steady state effects $d S / d \tau$ and $d S^{*} / d \tau$ by totally differentiating this two equation system and using Cramer's rule to find:

$$
\begin{aligned}
& d S / d \tau=\left(-A_{\tau} B_{S^{*}}+A_{S^{*}} B_{\tau}\right) / D \\
& d S^{*} / d \tau=\left(-A_{S} B_{\tau}+A_{\tau} B_{S}\right) / D
\end{aligned}
$$

where subscripts represent partial derivatives, and $D=A_{s^{*}} B_{s^{*}}-A_{s^{*}} B .>0$. Proposition 7 follows directly.

Proposition 7: Starting from free trade $(\tau=0)$, a marginal import tariff imposed by the domestic (labor abundant) country on imports of the resource good will have the following effects.

i) The domestic steady state resource stock will fall and the foreign steady state resource stock will rise $(\mathrm{dS} / \mathrm{d} \tau<0$ and $\mathrm{dS} * / \mathrm{d} \tau>0)$

ii) The domestic steady state price of the resource will rise and the foreign steady state price of the resource good will fall (dp/d $\tau>0$ and $d p * / d \tau<0)$.

iii) Foreign steady state utility rises and domestic steady state utility may either rise or fall.

Proof: i) and ii) See Appendix. iii) Since all individuals are identical, we can examine the welfare effects on a representative consumer with an endowment equal to that of the whole economy. Straightforward substitution of the foreign counterpart to (6) into the aggregate version of utility function (5) yields the aggregate indirect utility function for the foreign country:

$$
\mathrm{U}^{*}=\gamma \mathrm{I}^{*} \mathrm{p}^{*-\beta}
$$

where $\gamma=\beta^{\beta}(1-\beta)^{1-\beta}$ and $I^{*}=L^{*}$. Taking the derivative of $U^{*}$ with respect to $\tau$ yields

$$
d U^{*} / d \tau=-\gamma p^{-\beta} \beta\left(L^{*} / p^{*}\right) d p^{*} / d \tau>0
$$

It is easily seen that expression (30) is positive, as $\mathrm{dp}^{*} / \mathrm{d} \tau<0$ from part (ii) of the proposition. 
Domestic indirect utility can be written as $U=\gamma \mathrm{Ip}^{-\beta}$ where $\mathrm{I}=\mathrm{L}+\tau \mathrm{Z}$. Differentiating $\mathrm{U}$ with respect to $\tau$ then yields

$$
\mathrm{dU} / \mathrm{d} \tau=\gamma \mathrm{p}^{-\beta}(\mathrm{Z}-(\beta \mathrm{I} / \mathrm{p}) \mathrm{dp} / \mathrm{d} \tau)
$$

There are two effects of a tariff on domestic utility. There is a positive effect arising from tariff revenue, but a negative effect associated with the increase in the domestic price of the resource good. We have established by simulation that either of these effects may dominate. Therefore, there are cases in which both countries experience steady state gains from trade.

There are two surprising results given in Proposition 6. First, even though the world price of the resource good falls and the resource exporter suffers a terms of trade loss, the resource exporter gains (in steady state). The exporter gains because, when the world price falls, the foreign stock rebuilds to make harvesting a break-even activity again, and this has the effect of shifting out its steady state PPF. Since the foreign country is diversified, its consumption possibilities set also expands. Second, the home country may lose from the tariff even though it "benefits" from a terms of trade improvement. The potential domestic loss stems from the fact that the domestic relative price of the resource good rises. A higher domestic price for the resource leads to additional harvesting and to a lower steady state resource stock. The domestic PPF pivots in from this effect. The domestic country could still gain, however, because it also receives tariff revenue. Thus it is quite possible that both countries may gain (in steady state) from such a tariff, and this possibility can be verified using specific numerical examples.

\section{An Export Tax}

We now consider the imposition of an export tax by the exporter of the resource good (i.e. by the foreign country). Let the export tax be denoted by $\tau^{*}$. As before, the domestic and foreign prices must differ by the amount of the tax; that is, $p=p^{*}+\tau^{*}$. Expression (24) applies here as well: total consumption of the resource good must equal total production of the resource good. In this case, however, domestic income is simply $\mathrm{L}$, while foreign income is $\mathrm{L}^{*}+\tau * \mathrm{Z}$, because the foreign government collects 
the revenue associated with an export tax. Our two-equation system becomes:

$$
\begin{gathered}
\mathrm{A}\left(\mathrm{S}, \mathrm{S}^{*} ; \tau^{*}\right)=\beta \mathrm{L} \alpha \mathrm{S}+\beta\left(\mathrm{L}^{*}+\tau^{*} \mathrm{Z}\right) \alpha \mathrm{S}^{*}-\mathrm{rS}(1-\mathrm{S} / \mathrm{K})-\mathrm{r}^{*} \mathrm{~S}^{*}\left(1-\mathrm{S}^{*} / \mathrm{K}\right)=0 . \\
\mathrm{B}\left(\mathrm{S}, \mathrm{S}^{*} ; \tau^{*}\right)=1 / \alpha \mathrm{S}-1 / \alpha \mathrm{S}^{*}-\tau^{*}=0 .
\end{gathered}
$$

Totally differentiating this two equation system with respect to $S, S^{*}$, and $\tau *$ yields

$$
\begin{aligned}
& \mathrm{dS} / \mathrm{d} \tau^{*}=\left(-\mathrm{A}_{\tau^{*}} B_{\mathrm{S}^{*}}+\mathrm{A}_{\mathrm{S}^{*}} \mathrm{~B}_{\tau^{*}}\right) / D \\
& \mathrm{dS} * / \mathrm{d} \tau^{*}=\left(-\mathrm{A}_{\mathrm{s}} \mathrm{B}_{\tau^{*}}+\mathrm{A}_{\tau^{*}} \mathrm{~B}_{\mathrm{S}}\right) / \mathrm{D}
\end{aligned}
$$

\section{Proposition 8:}

Starting from a position of free trade, a marginal export tax has the following steady state effects.

i) The domestic resource stock falls and the foreign resource stock rises $\left(d S / d \tau^{*}<0\right.$ and $\left.d S^{*} / d \tau^{*}>0\right)$.

ii) The domestic price of the resource good rises while the foreign price falls (dp/d $\tau^{*}>0$ and $\mathrm{dp} * / \mathrm{d} \tau *>0)$.

iii) Domestic steady state utility falls and foreign steady state utility rises.

Proof: i) The proof is almost identical to the proof of part i) of Proposition 7 (which is given in the Appendix). ii) This follows from differentiation of $p=p^{*}+\tau^{*}$ with respect to $\tau^{*}$, in analogous fashion to the proof of Proposition 7, part ii. iii) Domestic welfare is given by $U=\gamma p^{-\beta} I$ where $I=L$. Hence

$$
\mathrm{dU} / \mathrm{d} \tau^{*}=\gamma \mathrm{p}^{-\beta} \beta(\mathrm{L} / \mathrm{p}) \mathrm{dp} / \mathrm{d} \tau^{*}<0
$$

using the fact that $d p / d \tau^{*}>0$ from part (ii). Foreign welfare is given by (29) where $I^{*}=L^{*}+\tau^{*} Z$. Substituting this for $I^{*}$, differentiating with respect to $\tau^{*}$, and rearranging yields

$$
\mathrm{dU}^{*} / \mathrm{d} \tau^{*}=\gamma \mathrm{p}^{*-\beta}\left(\mathrm{Z}-\mathrm{I}^{*}\left(\beta / \mathrm{p}^{*}\right) \mathrm{dp} \mathrm{p}^{*} / \mathrm{d} \tau^{*}\right)>0
$$

The fact that $\mathrm{dU}^{*} / \mathrm{d} \tau^{*}<0$ follows from the result of part ii that $\mathrm{dp} / \mathrm{d} \tau^{*}<0 . * * *$

The domestic country loses from the export tax because the tax raises the world relative price of the resource good and this leads to further stock depletion at home. The foreign country gains from the export tax because the tax depresses its relative price of the resource good and this leads to stock rebuilding. 
The central insight in both Propositions 7 and 8 is that any marginal policy intervention away from "laissez faire" that raises the relative price of the resource good in a particular country will, taken by itself, tend to create steady state losses for that country via resource depletion effects. These losses may be partially or even more than offset by revenues from the policy instrument, if that country is the recipient of those revenues. Conversely, a country where the relative price of the resource good is depressed by a policy instrument will tend to gain from the resulting resource accumulation, and these gains may be augmented by any revenues flowing directly from the policy instrument itself.

\section{Concluding Remarks}

This paper examines trade flows, gains and losses from trade, and the effects of trade policy in a two-good, two-country model in which one of the goods derives from harvesting an open access renewable resource. We are able to define an appropriate notion of factor proportions based on the ratio of the intrinsic growth rate of the resource to labor. We show that this ratio determines comparative advantage and the direction of the trade flow. The country with the higher ratio is effectively "resource abundant" and exports the resource good. Sufficient similarity across countries in factor proportions ensures diversified production in steady state and factor price equalization.

To the extent that the model captures an element of real trade flows, it suggests that incomplete property rights in renewable resource sectors undermine the presumption that trade liberalization is necessarily welfare-improving. Thus the claim that some countries are induced to over-exploit their renewable resources because of trade liberalization appears to have some merit. We find that the resource exporter must have lower steady state utility in a diversified trading steady state than in autarky, and in some cases will have lower instantaneous utility at every point along the transition path as well. Conversely, the resource importer always gains from trade. Furthermore, we have shown that diversified production is necessarily the result of trade if countries are sufficiently similar.

The model and analysis in this paper contain a number of limitations. First, the analysis is based 
on specific functional forms for production and for harvest growth. While the functional forms are not unreasonable, obviously the generality of the analysis is limited. We have undertaken some work with general functional forms which suggest that the economic forces identified in this paper are not merely artifacts of very special functional forms, but are fairly robust. It is, however, very difficult to obtain precise general results. Thus the model in this paper must be regarded as an example at this stage.

Also, we have not considered capital markets. If private agents (or governments) could take the proceeds from temporary resource rents earned in trade and invest these proceeds in an alternative asset such as physical capital or claims on future consumption, then the consumption path of private agents would be smoother than predicted here. However, the absence of capital markets is not critical for our results. The key problem is the externality created by open access. Opening capital markets does not reduce a marginal agent's incentive to move into harvesting when presented with a higher relative price for the product, nor does it eliminate the negative production externality created when this agent's harvesting lowers the common stock of the resource.

Our analysis stands as a marked counterpoint to the recent literature on trade and growth. In, for example, Baldwin (1992) and Grossman and Helpman (1991), trade liberalization may enhance welfare through dynamic effects on capital accumulation or on research and development. We abstract from such considerations, but clearly they are important, and we have no wish to understate them. However, renewable resource dynamics are also important and abstracting from them may lead to a rather optimistic assessment of the dynamic effects of trade liberalization.

As for our analysis of trade policy, we found that an import tariff that acts as a "countervail" to inadequate resource management practices may improve the steady state utility of both trade partners. Export taxes by resource exporters raise resource stocks in the exporting country and serve a conservationist end, but they reduce resource stocks elsewhere and lower utility in the importing country. An examination of production taxes is straightforward to carry out, but extensions to strategic interaction 
and to more complicated policy options are left to future work.

Overall, while there are various modifications to the paper that could be carried out, we believe that our structure provides a simple and flexible framework for examining some of the important policy issues associated with resource management and international trade. Here we have focused on one important concern that has received relatively little attention in the formal literature on international trade despite its significant practical importance: incomplete property rights in renewable resource sectors. While we are convinced that none of our results is sufficient reason to abandon ongoing trade liberalizations around the world, we are equally convinced that trade liberalization is a two-edged sword for a country with a comparative advantage in renewable resources and weak property rights in those sectors. 


\section{Appendix: Proofs of Propositions}

\section{Proof of Proposition 4}

i) Consider the possibility that the labor abundant country specializes in manufactures. In this case its wage is 1 . Over time, its resource stock grows to $\mathrm{K}$. Thus the implicit cost of producing the resource good is $\mathrm{a}_{\mathrm{LK}}(\mathrm{K})$. In the other (foreign) country the resource good is being produced. The foreign wage must be at least 1 (depending on whether manufactures are also being produced) and the stock must be less than $\mathrm{K}$. Therefore the cost of production (and world relative price) must be $w^{*} a^{*}{ }_{L K}\left(S_{T}\right)>a_{L K}(K)$. This implies that the (domestic) labor abundant country would certainly produce the resource good, contradicting the initial hypothesis. By similar reasoning, the resource abundant country cannot specialize in the manufacturing good either.

ii) To demonstrate ii) precisely requires a substantial amount of detailed algebra that we judge to be a poor use of space, so we report only the basic method of proof here. It is necessary to show that (16) is necessary and sufficient for diversification. To show necessity, assume diversification. Foreign demand

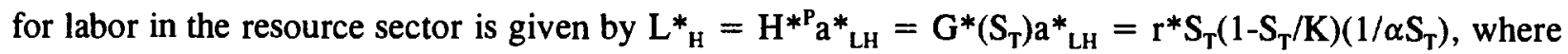
$\mathrm{S}_{\mathrm{T}}$, the common steady state stock, is given by (15). Simplifying this expression and imposing the condition that labor used in the resource sector cannot exceed total labor in the country yields expression (16). To show sufficiency, we assume that specialization occurs, note that $S^{*}=K\left(1-L^{*} \alpha / r^{*}\right)$ in this case, invoke overall material balance, and show that the inequality in (16) must run the other way. Thus, if (16) is satisfied, diversification is the only possibility.

iii) The proof of part ii) implies that if inequality (16) is not satisfied, then the resource abundant country specializes in the production of the resource good. Together with i) this proves iii).*** 
Proof of Proposition 7: (parts i and ii).

i) First we calculate the various components in comparative steady state expressions (27) and (28).

$A_{S}=\beta L \alpha-r(1-S / K)+r S / K, A_{S^{*}}=\beta L^{*} \alpha-r^{*}\left(1-S^{*} / K\right)+r^{*} S^{*} / K, A_{\tau}=\beta \alpha S M, B_{S}=-1 /\left(\alpha S^{2}\right)$,

$B_{S^{*}}=1 /\left(\alpha S^{* 2}\right)$, and $B_{\tau}=-1$.

Substituting the necessary partial derivative expressions into D yields

$$
\begin{aligned}
D=A_{S} B_{S^{*}}-A_{S^{*}} B_{S}=( & (\beta L \alpha-r(1-S / K)+r S / K) / \alpha S^{2}+\left(\beta L^{*} \alpha-r^{*}\left(1-S^{*} / K\right)+r^{*} S^{*} / K\right) / \alpha S^{* 2} \\
= & {\left[\beta L \alpha-r(1-S / K)+\beta L^{*} \alpha-r^{*}\left(1-S^{*} / K\right)\right] / \alpha S^{2}+\left(r+r^{*}\right) / \alpha K S } \\
= & \left(r+r^{*}\right) / \alpha K S>0 .
\end{aligned}
$$

In moving from (A1) to (A2) we have made use of the fact that $S=S^{*}\left(=S_{T}\right)$ at $\tau=0$. In moving from (A2) to (A3) we have used expression (25). Note that at $\tau=0, S=S^{*}$.

With $D>0$, we can sign comparative steady state effects $d S / d \tau$ and $d S^{*} / d \tau$ by evaluating the numerators in expressions (27) and (28). Define $\mathrm{N}$ as the numerator of expression (27) and $\mathrm{N}^{*}$ as the numerator of expression (28). The sign of comparative static effect $d S / d \tau$ is therefore given by the signs of $N . \quad N=A_{S^{*}} B_{\tau}-A_{\tau} B_{S^{*}}=-\left(\beta L^{*} \alpha-r^{*}\left(1-S^{*} / K\right)+r^{*} S^{*} / K\right)-\beta \alpha S Z / \alpha S^{* 2}$.

In order to simplify $\mathbf{N}$ we note that $S=S^{*}$ at $\tau=0$. We can also use the fact that domestic imports, $\mathrm{Z}$, must be the difference between foreign production and foreign consumption, implying that $\mathrm{Z}$ $=r^{*} S^{*}\left(1-S^{*} / K\right)-\beta \alpha L^{*} S^{*}$. Substituting $Z$ into our expression for $N$ and rearranging yields $N=\left[\beta^{2} \alpha L^{*}\right.$ $\left.\beta \alpha L^{*}\right]+r^{*}\left(1-2 S^{*} / K\right)-\beta r^{*}\left(1-S^{*} / K\right)$. The term in square brackets is obviously negative, since $\beta<1$. The remaining terms can be written as $r^{*}\left\{\left(1-2 S^{*} / K\right)-\beta\left(1-S^{*} / K\right)\right\}$. We therefore need to show that the expression inside the braces is negative. Recalling that $S^{*}=S_{T}$ at $\tau=0$, we can use (15) to substitute for $S^{*}$ in this expression in braces. We can think of this expression as a function of $\beta$ and write it as follows: $\phi(\beta)=\left(L+L^{*}\right) \alpha \beta /\left(r+r^{*}\right)-1 /(2-\beta)$. We wish to show that $\phi(\beta)<0$ for all relevant values of $\beta$. Relevant values of $\beta$ are those that can support a positive steady state stock. From (15), the expression $\left(\mathrm{L}+\mathrm{L}^{*}\right) \alpha \beta /\left(\mathrm{r}+\mathrm{r}^{*}\right)-1$ must be negative if $\mathrm{S}_{\mathrm{T}}=\mathrm{S}^{*}=\mathrm{S}$ is to be positive. However, this expression must 
exceed $\phi(\beta)$, since $1 /(2-\beta)<1$ for all $\beta<1$. Thus $\phi(\beta)$ must be negative, which proves that $d S / d \tau<$ 0.

We now show that $d S * / d \tau>0$. Sign $(d S * / d \tau)=\operatorname{sign}\left[A_{r} B_{S}-A_{S} B_{\tau}\right]=\operatorname{sign}\left[-\beta \alpha S Z / \alpha S^{2}+\beta L \alpha-\right.$ $\mathrm{r}(1-\mathrm{S} / \mathrm{K})+\mathrm{rS} / \mathrm{K}]=\operatorname{sign}[(1-\beta) \mathrm{Z} / \mathrm{S}+\mathrm{rS} / \mathrm{K}]>0$. In moving to the last equality we have used the fact that $\beta L \alpha-r(1-S / K)=-Z / S$, as domestic imports, $Z$, equal the difference between domestic consumption (given by $\alpha \beta L S$ ) and domestic production (given by $\mathrm{rS}(1-\mathrm{S} / \mathrm{K})$ ).

ii) follows immediately from (i). 


\section{REFERENCES}

Baldwin, Richard (1992) Measurable Dynamic Gains from Trade, Journal of Political Economy 100, 16274.

Barrett, S. (1994) Strategic Environmental Policy and International Trade, Journal of Public Economics 54, 325-38.

Brander, James A. and M. Scott Taylor (1995) International Trade and Open Access Renewable Resources: the Small Open Economy Case, NBER Working Paper No. 5021.

Brown, L.R.(1995) Nature's Limits, in Brown et. al. [ed.] State of the World 1995 (Norton: New York).

Chichilnisky, G. (1994) North-South Trade and the Global Environment, American Economic Review 84, 851-874.

Clark, Colin W. (1990) Mathematical Bioeconomics: The Optimal Management of Renewable Resources (2nd. ed.) (Wiley: New York).

Conrad, K. (1994) Emission Taxes and International Market Share Rivalry in E. van Ierland [ed.] International Environmental Economics (Elsevier: Amsterdam).

Cooper, Richard N. (1994) Environment and resource policies for the world economy (Brookings Institution: Washington, D.C.).

Copeland, Brian R. and M. Scott Taylor (1994) North-South Trade and the Environment, Quarterly Journal of Economics 755-787.

Copeland, Brian R. and M. Scott Taylor (1995), Trade and Trans-boundary Pollution, American Economic Review (forthcoming).

Deardorff, Alan V. (1973), The Gains from Trade in and out of Steady-State Growth, Oxford Economic Papers 25, 173-191.

Deardorff, Alan V. (1994), The Possibility of Factor Price Equalization, Revisited, Journal of International Economics 36, 167-75.

Dixit, A. and Norman V. (1980) The Theory of International Trade: a dual general equilibrium approach, (Cambridge University Press: Cambridge).

Ethier, Wilfred J. (1984) Higher Dimensional Issues in Trade Theory, in R.W. Jones and P. Kenen, eds., Handbook of International Economics. Vol. I (North Holland: Amsterdam).

Gordon, H. Scott (1954) The Economic Theory of a Common Property Resource: the Fishery. Journal of Political Economy 62, 124-42.

Grossman, Gene M. and Elhanan Helpman (1991) Innovation and Growth in the Global Economy (MIT 
Press: Cambridge, Mass.)

Kemp, M.C. and N.V. Long (1984), The Role of Natural Resources in Trade Models, in R. W. Jones and P.B. Kenen [eds], Handbook of International Economics. Vol. I, (North-Holland: Amsterdam).

Lear, W.H. and L.S. Parsons (1993), History and Management of the Fishery for Northern Cod in NAFO Divisions $2 \mathrm{~J}, 3 \mathrm{~K}$, and $3 \mathrm{~L}$, in Parsons and Lear [eds] Perspectives on Canadian marine fisheries management, Canadian Bulletin of Fisheries and Aquatic Sciences no. 226, pp. 55-90, (Canadian Department of Fisheries and Oceans: Ottawa).

Lopez, Ramon (1994), The Environment as a Factor of Production: The Effects of Economic Growth and Trade Liberalization, Journal of Environmental Economics and Management 27, 163-84.

Markusen, J. (1976), Production and Trade from International Common Property Resources, Canadian Journal of Economics 9, 309-19.

McRae, J. (1978), Optimal and Competitive Use of Replenishable Natural Resources by Open Economies, Journal of International Economics, 8, 29-54.

Munro, Gordon R. and Anthony D. Scott (1985) "The Economics of Fisheries Management", Handbook of Natural Resource and Energy Economics, vol. II, Ch. 14, ed. by A.V. Kneese and J.L. Sweeney (North-Holland: Amsterdam).

Neher, Philip (1990), Natural Resource Economics: Conservation and Exploitation (Cambridge Unversity Press: Cambridge.)

Pearce, David W. and Jeremy Warford (1993) World without end: Economics, environment and sustainable development (Oxford University Press: Oxford).

Rauscher, Michael (1993) On Ecological Dumping, Oxford Economic Papers, 46, 822-840.

Scott, A.D.(1955) The Fishery: the Objectives of Sole Ownership, Journal of Political Economy 63, 11624.

Scott, A. and C. Southey (1969), The Problem of Achieving Efficient Regulation of a Fishery, in A. Scott [ed.], The Economics of Fishery Management: A Symposium. Institute of Animal Resource Ecology, University of British Columbia, Vancouver, B.C.

Schaefer, M.B. (1957) Some Considerations of Population Dynamics and Economics in Relation to the Management of Marine Fisheries, Journal of the Fisheries Research Board of Canada, 14:669-681.

Srinivasan, T.N. and J.N. Bhagwati (1980) Trade and Welfare in Steady State in J. Chipman and C. Kindleberger [ed.] Flexible Exchange Rates and the Balance of Payments (North-Holland: Amsterdam).

World Bank (1992), A Study of International Fisheries Research, in collaboration with the United Nations Development Programme, the Commission of the European Communities, and the Food and Agriculture Organization of UN, Washington, D.C. 